Jurnal Laut Khatulistiwa, Vol. 4 No. 2 (Julii, 2021), Hal. 22-28.

ISSN : 2614-6142 (Printed), 2614-8005 (Online)

http://jurnal.untan.ac.id/index.php/lk

JURNAL LAUT

KHATULISTIWA

\title{
Struktur Komunikasi Terumbu Karang di Perairan Teluk Melanau Timur, Pulau Lemukutan
}

\section{Coral Reef Community Structure In East Melanau Bay, Lemukutan Island}

\author{
Taufik Nurcahyanto ${ }^{1}$, Muliadi2 ${ }^{2}$, Yusuf Arief Nurrahman ${ }^{3}$ \\ 1 Program Studi Ilmu Kelautan, FMIPA Universitas Tanjungpura, Pontianak, Indonesia \\ ${ }^{2}$ Laboratorium Ilmu Kelautan, FMIPA Universitas Tanjungpura, Pontianak, Indonesia \\ *E-mail : taufikcy@gmail.com
}

Received : 1 Juli 2021; Accepted: 10 Juli 2021

Published: 31 July (C) Author(s) 2021. This article is open access

\begin{abstract}
This research aims to determine the structure of the coral reefs community and to determine the condition of the environmental parameter that affect the growth of the coral reefs in East Melanau Bay, Lemukutan Island. This research used an exploratory method with data collection technique used the line intercept transect method from 3 stations and two different depths (2-3 $\mathrm{m}$ and 5-6 $\mathrm{m}$ ). The results of this research showed that coral reef cover at a depth of 2-3 meters ranged from 17,76\% to 38,06\% and at a depth of 5-6 meters ranged from $11,14 \%$ to $48,28 \%$. Diversity index values ranged from 0,80 to 1,74 , the uniformity index ranged from 0,57 to 0,82 , and the dominance index ranged from 0,21 to 0,57 .
\end{abstract}

Keywords : Coral Reef, Line Intercept Transect, Live Coral Cover, Community Structure.

\begin{abstract}
Abstrak
Tujuan dari penelitian ini adalah untuk mengetahui struktur komunitas terumbu karang dan mengetahui kondisi parameter lingkungan yang mempengaruhi pertumbuhan terumbu karang di Teluk Melanau Timur, Pulau Lemukutan. Penelitian ini menggunakan metode eksploratif dengan teknik pengambilan data menggunakan metode line intercept transect (LIT) dari 3 stasiun dan dua kedalaman berbeda (2-3 m dan 5-6 m). Hasil penelitian diperoleh tutupan terumbu karang pada kedalaman 2-3 m berkisar antara 17,76\% sampai $38,06 \%$ dan pada kedalaman 5-6 m berkisar antara $11,14 \%$ sampai $48,28 \%$. Nilai indeks keanekaragaman berkisar antara 0,80 sampai 1,74 , indeks keseragaman berkisar antara 0,57 sampai 0,82 , indeks dominansi berkisar antara 0,21 sampai 0,57.
\end{abstract}

Kata kunci : Terumbu Karang, Line Intercept Transect, Tutupan Karang Hidup, Struktur Komunitas.

\section{Pendahuluan}

Berdasarkan data yang dipublikasi oleh Global Coral Reef Monitoring Network (GCMRN) tahun 2008, kurang lebih $54 \%$ terumbu karang dunia berada dalam kondisi terancam secara global (Suryono, 2018). Kerusakan Terumbu karang di Indonesia lebih banyak disebabkan oleh berbagai kegiatan manusia dalam pemanfaatan sumber daya laut (Yusuf, 2013).

Jumlah aktivitas pariwisata yang meningkat, kegiatan penangkapan ikan yang tidak ramah lingkungan, perubahan lingkungan serta kurangnya penelitian tentang kondisi terumbu karang di Pulau Lemukutan, terlebih di Teluk Melanau Timur, memiliki dampak negatif yang sangat berpengaruh bagi ekosistem terumbu karang dan pada akhirnya akan berpengaruh dengan berkurangnya keanekaragaman organisme yang hidup di lingkungan terumbu karang dan berakibat menurunnya jumlah tangkapan ikan di Pulau Lemukutan.

Berdasarkan permasalahan yang disebutkan, upaya konservasi atau pelestarian 
terumbu karang dapat dijadikan salah satu alternatif untuk mengurangi dan memperbaiki kesimbangan ekosistem terumbu karang dengan mengetahui struktur komunitas terumbu karang dan kondisi parameter lingkungan yang mempengaruhi pertumbuhan terumbu karang di Teluk Melanau Timur, Pulau Lemukutan.

Tujuan dari penelitian ini adalah mengetahui struktur komunitas terumbu karang dan mengetahui kondisi parameter lingkungan yang mempengaruhi pertumbuhan terumbu karang di Teluk Melanau Timur sebagai kawasan pengelolaan konservasi laut khususnya terumbu karang.

\section{Metodologi Penelitian}

\subsection{Waktu dan Lokasi Penelitian}

Penelitian dilaksanakan di Perairan Pulau Lemukutan, Teluk Melanau Timur, Kabupaten Bengkayang, Kalimantan Barat, pada bulan Agustus tahun 2020. Penelitian dilakukan dengan tiga stasiun pengamatan. Pengamatan struktur komunitas terumbu karang dan pengukuran parameter fisika-kimia dilakukan secara in-situ.

\subsection{Analisis Data}

Metode pengambilan data yang dilakukan dalam penelitian ini meliputi beberapa tahap, yaitu: penentuan titik lokasi menggunakan metode Eksploratif, pengambilan sampel data menggunakan metode Line Intercept Transect (LIT) menurut English et al., (1994). Setelah didapat lokasi yang tepat, dilakukan penyelaman dengan meletakkan Line Transek sepanjang $50 \mathrm{~m}$ sejajar dengar garis pantai. Pengambilan data dilakukan pada kedalaman antara 2-3 m dan 5-6 m. Pengelompokan komunitas karang dilakukan menggunakan kategori bentuk tumbuh (life form) dengan melihat tutupan karang hidup/mati, substrat (pasir, lumpur), alga dan biota lain. Visual jalur transek disajikan pada Gambar (2).

Parameter fisika-kimia lingkungan perairan seperti suhu, salinitas, kecerahan, kedalaman, $\mathrm{pH}, \mathrm{DO}$, arus juga diukur dalam penelitian ini bertujuan untuk memperoleh data yang mendukung pendataan ekosistem terumbu karang.

\subsection{Analisis Data}

Data yang telah diperoleh kemudian diolah secara deskriptif dan dianalisis untuk mengetahui struktur komunitas terumbu

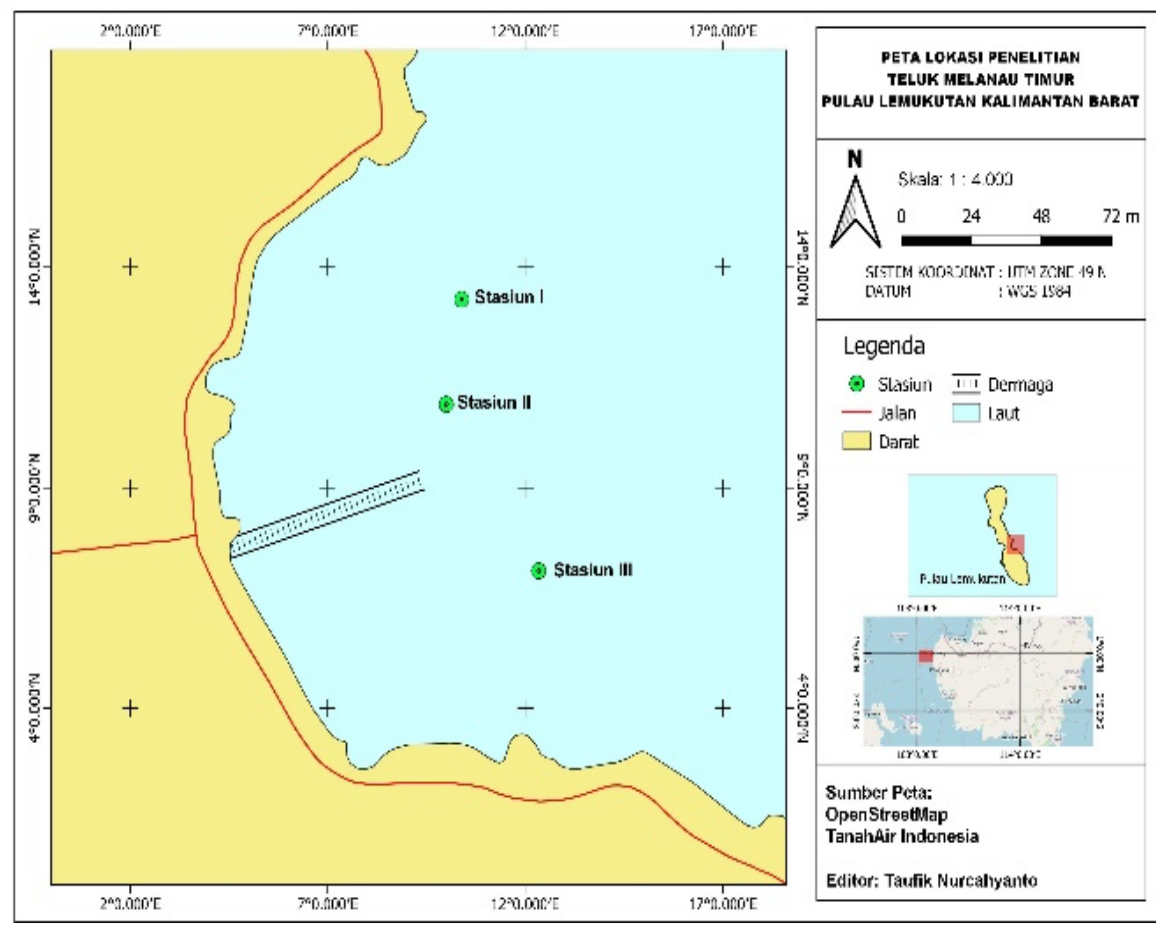

Gambar 1. Peta lokasi penelitian 
Jurnal Laut Khatulistiwa, Vol. 4. No. 2 (July, 2021), Hal. 22-28.

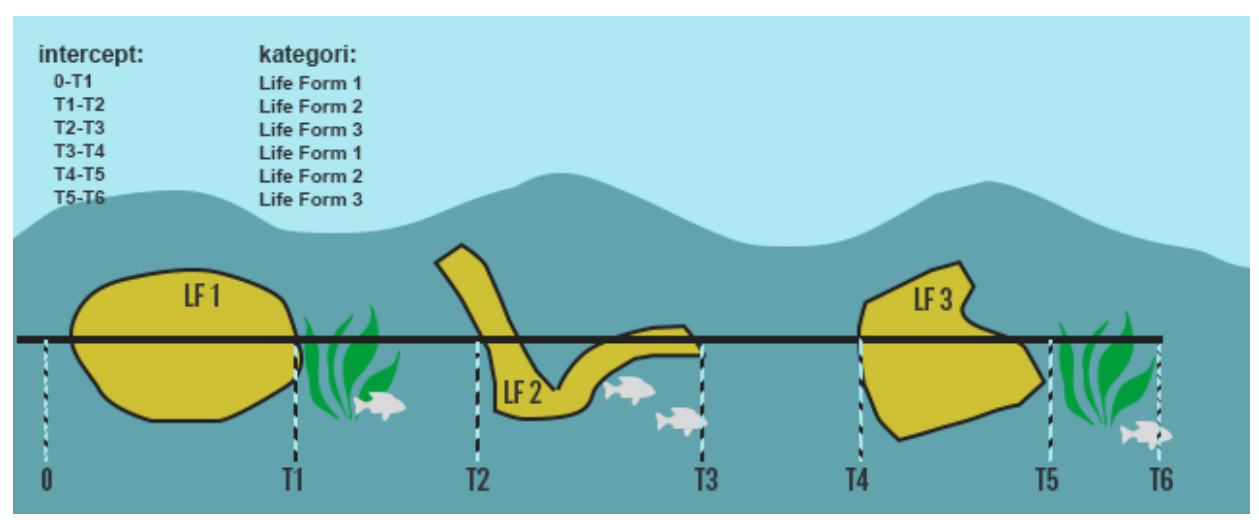

Gambar 2. Cara pencatatan data pada metode Line Intercep Transect (LIT)

karang di perairan Teluk Melanau Timur, Pulau Lemukutan. Data persentase Tutupan Karang, Indeks Keanekaragaman ( $\left.\mathrm{H}^{\prime}\right)$, Indeks Keseragaman (E) dan Indeks Dominansi (C) dihitung menggunakan persamaan berikut:

- Persentase Tutupan Karang (English et al., 1997)

$$
L=\frac{L i}{N} X 100 \%
$$

Dimana $L$ adalah persen tutupan karang (\%), $L i$ adalah Panjang tutupan setiap life form, $N$ adalah Panjang transek.

- Indeks Keanekaragaman $\left(\mathrm{H}^{\prime}\right)$ Shanon Wiener (Bengen, 2000)

$$
\boldsymbol{H}^{\prime}=-\sum_{i=1}^{S} \text { pi ln pi }
$$

Dimana $H^{\prime}$ adalah Indeks Keragaman Shannon Wiener, pi adalah jumlah individu suatu spesies, $S$ adalah jumlah total individu.

- Indeks Keseragaman (E) Shanon Wiener (Krebs, 2014)

$$
E=\frac{H^{\prime}}{H^{\prime} \max }
$$

Dimana $E$ adalah Indeks keseragaman, $H^{\prime}$ adalah keseimbangan spesies, $H^{\prime} \max$ adalah indeks keanekaragaman maksimum.

- Indeks Dominansi (C) Shannon Wiener (Odum, 1971)

$$
C=\sum_{i=1}^{S} p i^{2}
$$

Dimana $C$ adalah indeks dominansi, $p i$ adalah proporsi jumlah individu pada spesies karang, $S$ adalah $1,2,3, . . \mathrm{n}$

\section{Hasil dan Pembahasan \\ 3.1. Tutupan Terumbu Karang}

Secara umum, terumbu karang di Teluk Melanau Timur, Pulau Lemukutan berada pada kondisi sedang hingga buruk. Hasil pengamatan didapat struktur komunitas terumbu karang beragam. Kategori tutupan karang mengikuti Gomes dan Yap (1984) Tabel (1)

Pendataan tutupan pada kedalaman 2-3 m menunjukkan persentase Hard Coral tertinggi terdapat pada stasiun 3 yaitu $38,06 \%$ sedangkan pada stasiun 1 sebesar $17,76 \%$ dan pada stasiun 2 yaitu 21,32\%. Berdasarkan kategori tutupan karang menurut Gomes dan Yap (1984) pada stasiun 1 dan 2 tergolong buruk, pada stasiun 3 tergolong sedang. Faktor yang mempengaruhi persentase Hard Coral rendah dan tingginya komponen abiotik pada stasiun 1 yakni adanya aktivitas manusia yaitu keluar masuk dan penambatan kapal nelayan sehingga mengakibatkan terjadinya patahan karang (rubbles), kerusakan karang dan karang mati. Fakta ini disokong Burke et al., (2002) menyatakan ada beberapa penyebab kerusakan terumbu karang seperti aktivitas dari kapal dan pelabuhan termasuk kegiatan buang jangkar kapal memiliki dampak negatif yaitu karang hancur, patah, terbongkar, 
Jurnal Laut Khatulistiwa, Vol. 4. No. 2 (July, 2021), Hal. 22-28.

Tabel 1. Kategori Persentase Tutupan Karang

\begin{tabular}{cc}
\hline Tutupan (\%) & Kategori \\
\hline $0-24,9$ & Buruk \\
$25-49,9$ & Sedang \\
$50-74,9$ & Baik \\
$75-100$ & Sangat Baik \\
\hline
\end{tabular}

sehingga menyebabkan persentase tutupan karang, kelimpahan dan diameter koloni karang berubah dan menurun, akan terjadi peningkatan persentase tutupan karang mati dan patahan karang (rubbles). Pada stasiun 2 adanya aktivitas manusia yaitu banyak wisatawan melakukan kegiatan berenang dan snorkling yang menyebabkan rusaknya karang akibat tertijak secara sengaja ataupun tidak disengaja. Hal ini dipertegas Sukmara et al., (2001) yang mengatakan bahwa dampak dari aktifitas berjalan diatas karang adalah dapat membuat karang patah-patah dan rusak.

Pendataan tutupan pada kedalaman 5-6 m menunjukkan persentase Hard Coral tertinggi pada stasiun 2 dengan persentase tutupan karang hidup yaitu $48,28 \%$ sedangkan pada stasiun 1 persentase tutupan karang hidup yaitu $11,14 \%$ dan stasiun 3 persentase tutupan karang hidup yaitu 22,66\%. Berdasarkan kategori tutupan karang menurut Gomes dan Yap (1984) pada stasiun 1 dan stasiun 3 tergolong buruk sedangkan tutupan pada stasiun 2 tergolong sedang. Rendahnya tutupan Hard Coral pada stasiun 1 dan 3 disebabkan ketiadaan substrat karang yang mencukupi untuk pertumbuhan karang. Tidak ditemukannya substrat keras seperti patahan karang dan batu yang dapat membantu pertumbuhan karang, substrat yang mendominasi pada kedalaman 5-6 m adalah SI dan SD yang termasuk komponen abiotik, hal ini yang menjadikan komponen abiotik sangat tinggi pada stasiun 1 dan 3. Fakta ini disokong oleh Nababan (2009) menyatakan bahwa hewan karang membutuhkan substrat keras seperti batu, atau besi untuk membantu menempel, hidup dan berkembang.

Hasil perhitungan nilai indeks Keanekaragaman $\left(\mathrm{H}^{\prime}\right)$, Keseragaman(E), dan Dominansi (C) pada setiap stasiun pengamatan dapat dilihat pada (Gambar 5). Indeks keanekaragaman diartikan sebagai suatu penggambaran secara sistematik untuk struktur komunitas dan dapat mempermudah proses analisa mengenai jumlah organisme.

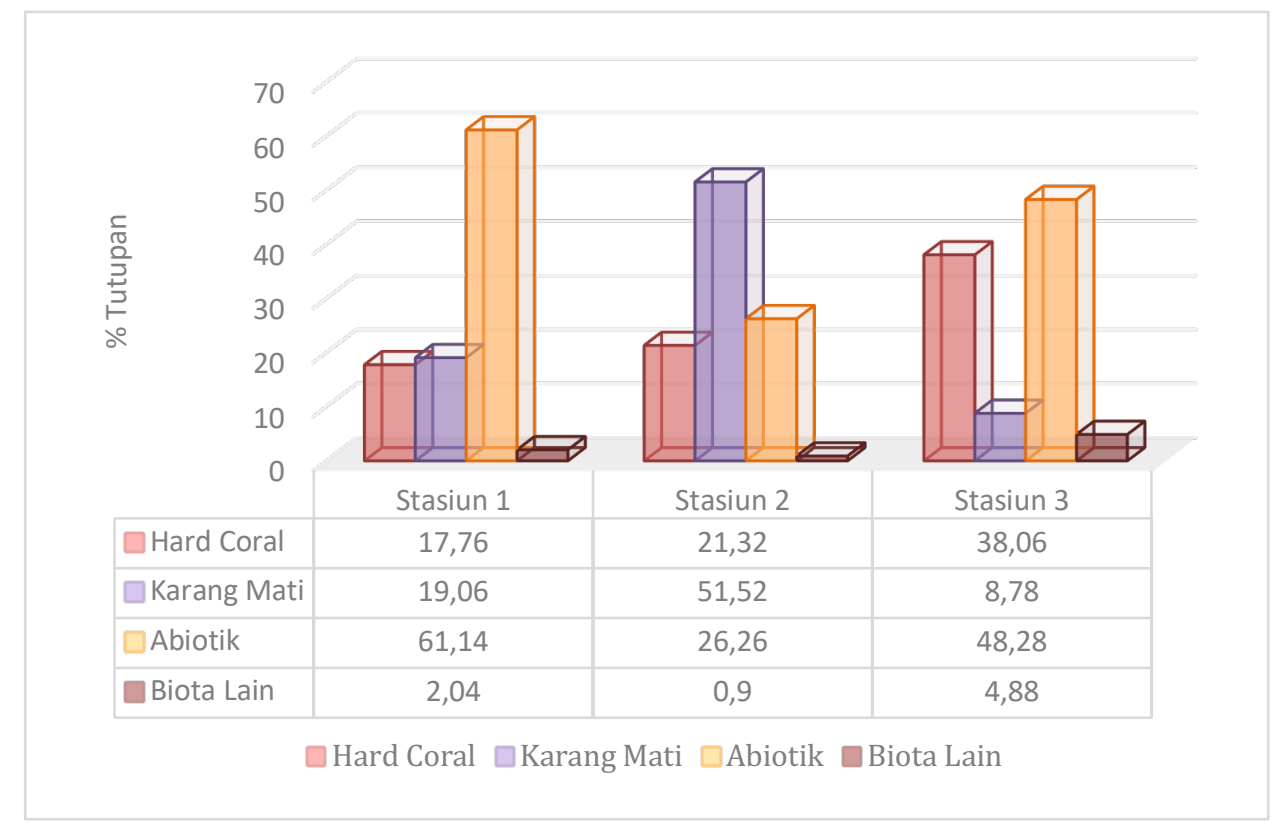

Gambar 3. Persentase Tutupan Kedalaman 2-3 Meter 
Jurnal Laut Khatulistiwa, Vol. 4. No. 2 (July, 2021), Hal. 22-28.

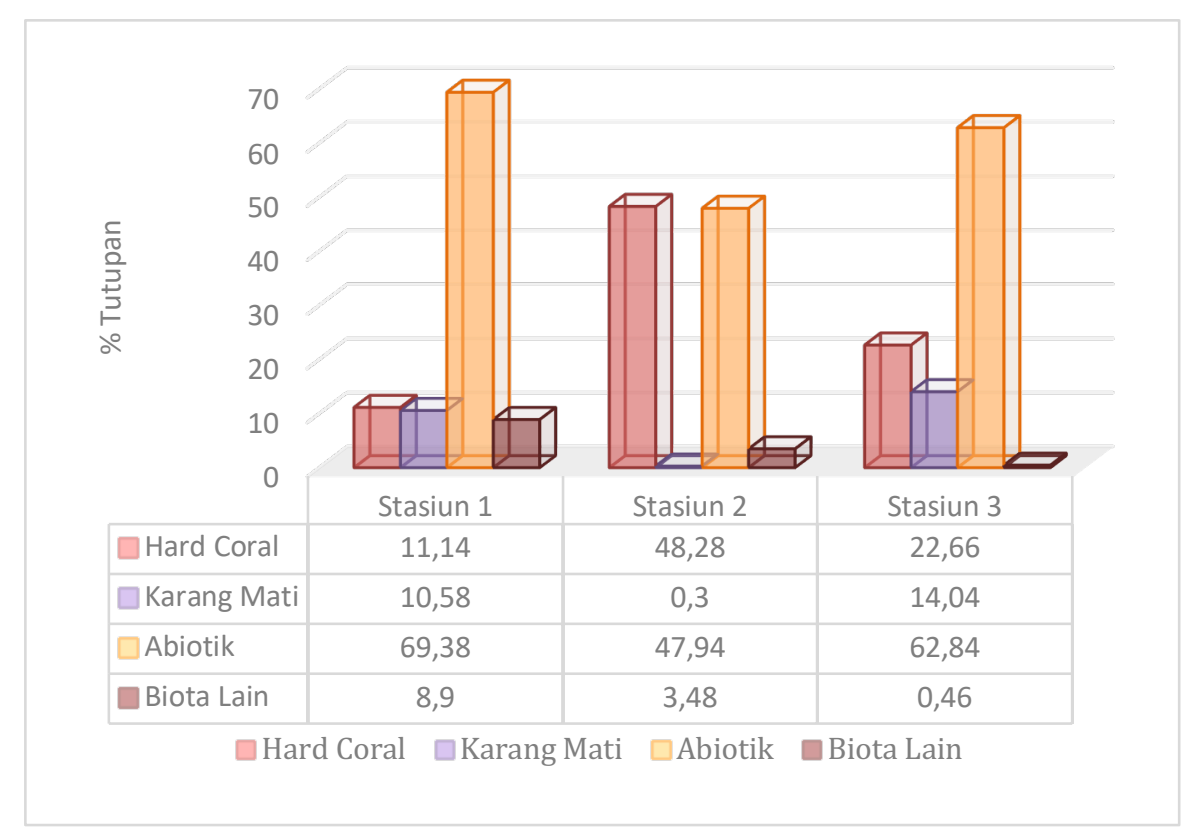

Gambar 4. Persentase Tutupan Kedalaman 5-6 Meter

Pada stasiun 1 kedalaman 2-3 m dan 5-6 m memiliki nilai masing-masing sebesar 1,01 dan 1,70 termasuk dalam kategori sedang. Pada stasiun 2 kedalaman 2-3 m dan 5-6 m memiliki nilai masing-masing sebesar 1,22 dan 1,45 termasuk dalam kategori sedang, pada stasiun 3 kedalaman 2-3 m memiliki nilai yaitu 1,74 termasuk dalam kategori sedang dan pada kedalaman 5-6 m memiliki nilai 0,80 termasuk dalam kategori rendah. Nilai indeks keanekaragaman karang di tiap-tiap stasiun penelitian menunjukkan kategori rendah sampai sedang, tidak ada keanekaragaman yang tinggi.

Indeks keseragaman pada stasiun 1 kedalaman 2-3 m dan 5-6 m memiliki nilai masing-masing sebesar 0,73 dan 0,82 termasuk dalam kategori keseragaman tinggi, komunitas stabil. Pada stasiun 2 kedalaman 2$3 \mathrm{~m}$ dan 5-6 m memiliki nilai masing-masing sebesar 0,62 dan 0,69 termasuk dalam kategori keseragaman tinggi, komunitas stabil. Pada stasiun 3 kedalaman 2-3 m memiliki nilai yaitu 0,79 termasuk dalam kategori keseragaman tinggi, komunitas stabil dan pada kedalaman 5-6 m memiliki nilai yaitu 0,57 termasuk dalam kategori keseragaman sedang, komunitas labil. Nilai indeks keseragaman karang di tiap-tiap stasiun penelitian menunjukkan kategori komunitas labil sampai stabil, tidak ditemukan komunitas tertekan.

Nilai indeks dominansi pada stasiun 1 kedalaman 2-3 m dan 5-6 m memiliki nilai masing-masing sebesar 0,40 dan 0,22 termasuk kategori rendah. Pada stasiun 2 kedalaman 2-3 m dan 5-6 m memiliki nilai masing-masing sebesar 0,42 dan 0,31 termasuk kategori rendah. Pada stasiun 3 kedalaman 2-3 m memiliki nilai yaitu 0,21 termasuk kategori rendah dan pada kedalaman 5-6 m memiliki nilai yaitu 0,57 termasuk kategori sedang. Nilai indeks dominansi karang di tiap-tiap stasiun penelitian menunjukkan kategori rendah sampai sedang, hal ini menandakan tidak ada karang yang mendominansi. Menurut Odum (1998), apabila semakin tinggi nilai dominansi maka dapat mempengaruhi kestabilan komunitas dan kemerataan jenis karang.

\subsection{Kondisi Umum Perairan}

Suhu perairan di daerah pengamatan pada stasiun 1 dan 2 berkisar $29,7^{\circ} \mathrm{C}-29,8^{\circ} \mathrm{C}$ pengukuran dilakukan pada pagi hari, pada stasiun 3 berkisar $30,2^{\circ} \mathrm{C}-30,3^{\circ} \mathrm{C}$ pengukuran dilakukan pada siang hari. Kondisi ini memperlihatkan keadaan yang bersifat normal dimana terumbu karang masih dapat hidup dan berkembang. Menurut Nontji (1993) menyatakan temperatur di permukaan 
Jurnal Laut Khatulistiwa, Vol. 4. No. 2 (July, 2021), Hal. 22-28.

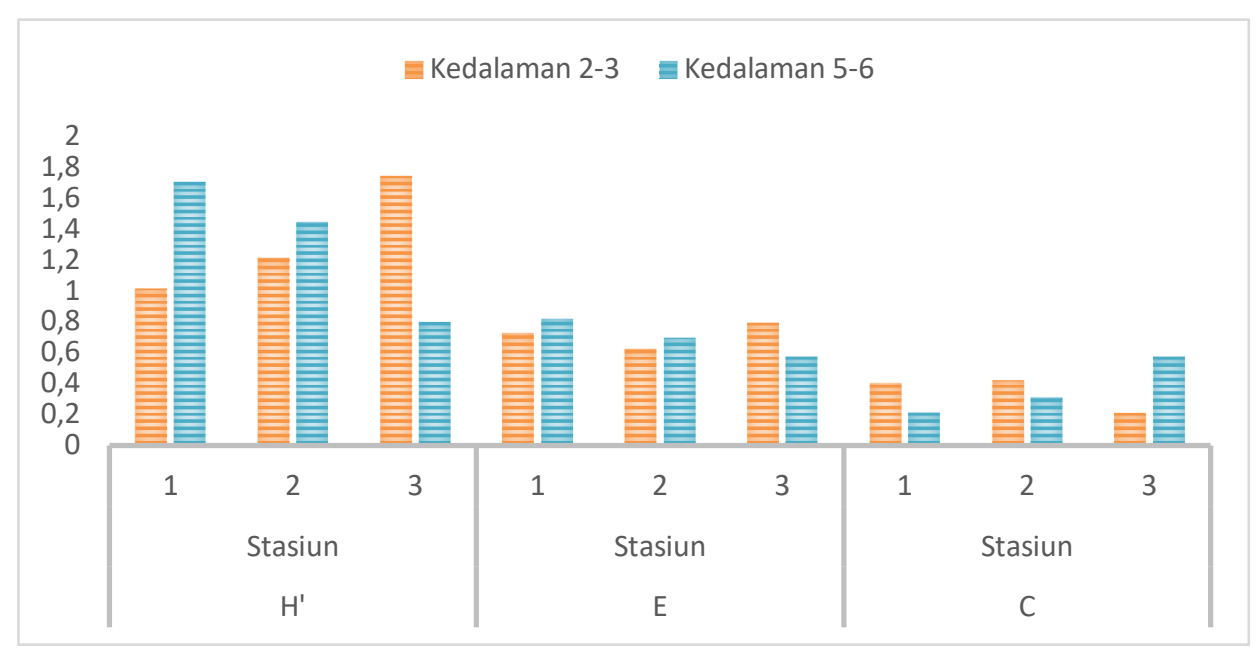

Gambar 5. Indeks Keanekaragaman( $\left.\mathrm{H}^{\prime}\right)$, Keseragaman(E), dan Dominansi (C)

perairan nusantara umumnya berkisar $28,00^{\circ} \mathrm{C}-31,00^{\circ} \mathrm{C}$. Suhu yang optimal bagi pertumbuhan terumbu karang berkisar $28^{\circ} \mathrm{C}-$ $30^{\circ} \mathrm{C}$ (KepMen LH No. 51 tahun 2004).

Oksigen terlarut (DO) perairan di daerah pengamatan pada stasiun 1 berkisar $5,2 \mathrm{mg} / \mathrm{l}$ $5,4 \mathrm{~g} / \mathrm{l}$, pada stasiun 2 berkisar $5,01 \mathrm{mg} / \mathrm{l}-$ $5,06 \mathrm{mg} / \mathrm{l}$, pada stasiun 3 berkisar $5,1 \mathrm{mg} / \mathrm{l}-$ $5,4 \mathrm{mg} / \mathrm{l}$. Kondisi ini masih masuk kategori baik jika dilihat berdasarkan KepMen LH No.51 tahun 2004 tetang baku mutu perairan untuk biota yaitu sebesar $>5 \mathrm{mg} / \mathrm{l}$.

Nilai salinitas perairan di daerah pengamatan pada stasiun 1 yaitu $32,1 \% 0^{-}$ $32,1 \%$ o0, pada stasiun 2 yaitu $31,2 \% / 00-32,3 \%$, pada stasiun 3 yaitu $32 \% 00-32,2 \%$ oo. Nilai salinitas perairan di daerah pengamatan tergolong rendah menurut KepMen LH No.51 tahun 2004 dengan berkisar nilai 33\% $0^{-}$ $44 \%$ o0. Menurut Sudiarta (1995) menyatakan hewan karang memiliki toleransi salinitas berkisar $270 \% 00^{-40} \%$, sedangkan Menurut patty (2013) perairan di Indonesia memiliki rentang salinitas antara 31\% $00-35 \%$. Mengacu pada penjelasan tersebut kondisi salinitas di perairan daerah penelitian masuk pada kategori baik untuk pertumbuhan dan perkembangan terumbu karang.

Nilai pH perairan di daerah pengamatan pada stasiun 1 yaitu 8,04-8,05, pada stasiun 2 yaitu 8,05-8,09, pada stasiun 3 yaitu 8,02-8,07. Menurut KepMen LH No. 51 tahun 2004 tentang baku mutu perairan untuk biota yaitu berkisar 7-8,5. Nilai pH di daerah pengamatan tergolong dalam kondisi baik atau normal untuk keberlangsungan biota.
Kecerahan pada perairan di daerah pengamatan yaitu 4,8 meter. Nilai tersebut masih belum mencapai baku mutu standar kecerahan perairan yang baik untuk kehidupan biota. Berdasarkan KepMen LH No. 51 tahun 2004 menyatakan baku mutu air laut untuk kehidupan biota yaitu $>5$ meter. Pengambilan data kecerahan dilakukan disatu titik yang dianggap dapat mewakili semua stasiun pengamatan sehingga dianggap keseluruhan stasiun sama hasilnya.

Kecepatan arus pada perairan di daerah pengamatan diperoleh rata-rata kecepatan arus yaitu $0,0658 \mathrm{~m} / \mathrm{s}$. Nilai ini tergolong baik bagi pertumbuhan terumbu karang. Hal ini disokong pernyataan Suharsono (1991), arus yang optimal bagi terumbu karang yaitu 0,05$0,08 \mathrm{~m} / \mathrm{s}$. Pengambilan data dilakukan disatu titik yang dianggap mewakili semua stasiun pengamatan sehingga dianggap keseluruhan stasiun sama hasilnya.

\section{Kesimpulan}

Persentase tutupan karang di Teluk Melanau Timur Pulau Lemukutan kedalaman 2-3 m berada pada kisaran 17,76-38,06\% atau pada kondisi buruk hingga sedang. Pada kedalaman 5-6 m berada pada kisaran 11,14$48,28 \%$ atau pada kondisi buruk hingga sedang.

Nilai indeks keanekaragaman karang berkisar 0,80-1,74, indeks keseragaman berkisar 0,57-0,82, indeks dominansi berkisar 0,21-0,57.

Kondisi umum fisik kimia lingkungan perairan tergolong baik untuk pertumbuhan 
terumbu karang, sedangkan kecerahan perairan tergolong rendah.

\section{Ucapan Terima Kasih}

Penulis mengucapkan terima kasih kepada Kementerian Riset, Teknologi, dan Pendidikan Tinggi untuk Program Beasiswa Bidikmisi yang ditangani Comdev dan Outreaching Universitas Tanjungpura, Dosen Pembimbing serta tim Shark Diver yang membantu proses pengambilan data.

\section{Daftar Pustaka}

Abdurrahmat, F. 2011. Metodologi Penelitian Tekhnik Penyusunan. Bineka Cipta, Jakarta. (Skripsi). 99 hal.

Bengen, D.G. 2000. Teknik Pengambilan Contoh dan Analisis Data Biofisik Sumberdaya Pesisir, PKSPL IPB. Bogor. 88 hal.

Burke, L., E. Selig. dan M. Spallding. 2002. Terumbu karang yang Terancam di Asia Tenggara, Ringkasan Untuk Indonesia, Terjemahan dari Reefs at Risk in Southeast Asia. Kerjasama antara WRI, UNEP, WCMC, ICLARM dan ICRAN. 40 hal.

English, S., C. Wilkinson dan V. Baker. 1994. Survey Manual for Tropical Marine Resources, Australian Institute of Marine Sciences,Townsville.

English, S., C. Wilkinson dan V. Baker. 1997, Survey Manual for Tropical Marine Resources, Australia: ASEAN - Australia Marine Science Project Living Coastal Resources.

Gomes, E.D. dan H. Yap. 1984. Monitoring Reef Condition. Dalam Kenchington, R.A, dan B. Hudson E.T. (ed). Coral Reef Management Hand Book. Unesco Regional Office for Science and Technology for South East Asia, Jakarta, 187-195 pp.

Kementerian Lingkungan Hidup [KLH]. 2004. Keputusan Menteri Lingkungan Hidup No.51/MENLH/2004 tentang Baku Mutu Air Laut Untuk Biota Laut.Jakarta.

Krebs. 2014. Ecological Methodology (Fourth Edition), Ecology at the University of Canberra and the Biodiversity Center at the University of British Columbia, Camberra.

Mulya, M.B. 2006. Kondisi Terumbu Karang Hidup Berdasarkan Persen Tutupan di Pulau Karang Provinsi Sumatera Utara dan Hubungannya Dengan Kualitas
Perairan, Jurnal Komunikasi Penelitian. 18 (2):1-6.

Nababan, T.M., 2009, Persen Tutupan (Percent Cover) Terumbu Karang di Bagian Timur Perairan Pulau Rubiah Nanggroe Aceh Darussalam. Skripsi Departemen Biologi Fakultas Matematika dan Ilmu Pengetahuan Alam Universitas Suma-Tera Utara.

Nontji, A. 1993. Laut Nusantara, Penerbit Djambatan, Jakarta. 376 hal.

Odum, E.P. 1971. Fundamental of Ecology, 3 rd Edition, W.B Sounders Co, Philadelphia dan London, IPB, Bogor.

Odum, E.P. 1998. Fundamentals of Ecology, 5rd Edition, Holt, Reinhart, Winston, Inc, New York. 697 p.

Patty. 2013. Distribusi Suhu, Salinitas, dan Oksigen Terlarut di Perairan Kema, Sulawesi Utara, LIPI, Jakarta.

Pranata, N.B., Muliadi danA.S.S. Sanova. 2018. Kondisi Ekosistem Terumbu Karang di Teluk Cina, Pulau Lemukutuan, Kalimantan Barat. J. Laut Khatulistiwa, 1(2):9-16.

Sudiarta, I. K. 1995. Struktur Komunitas Biota Ekosistem Terumbu Karang dan Pemintakatan Kawasan Wisata Bahari Pulau Lembongan,Bali, Program Pasca Sarjana Institut Pertanian Bogor.

Suharsono. 1991. Bulu seribu (Acanthaster planci), Balai Penelitian dan Pengembangan Biologi Laut, Puslitbang Oseanologi-LIPI, Jakarta. 16(3):17.

Sukmara, A., A. Siahainenia. dan C. Rotinsulu. 2001. Panduan Pemantauan Terumbu Karang Berbasis Masyarakat. Coastal Resources Center, Proyek Pesisir, CRC/URI CRMP, NRM, Jakarta.

Suryono, W. Edi, A. Raden, T.S.P.J. Nur dan A.T.N. Ria. 2018. Kondisi Terumbu Karang di Perairan Pantai Empu Rancak, Mlonggo, Kabupaten Jepara. J. Kelautan Tropis. 21(1):49-54. 